\title{
Technique
}

\section{A modification to the method of George for studying gastric emptying}

\section{J. N. HUNT From the Department of Physiology, Guy's Hospital Medical School, London}

The method of George (1968) is convenient for studying gastric function. However, it does not seem to be widely appreciated that the method gives information only on the change in the volume of the gastric contents with time. This is determined by the difference between the rate of gastric emptying and the rate of gastric secretion. When the rate of gastric secretion equals the rate of gastric emptying the method indicates constant intragastric volume. This restriction on the interpretation of the results of the method of George can be overcome by using information about gastric secretion based on the chloride in the gastric contents.

Some data are needed to illustrate this discussion. The table shows means for measurements made on 21 subjects (Hunt and Spurrell, 1951). The observations were made by withdrawing the whole gastric contents at different times on different days. In this way errors caused by incomplete mixing of gastric secretions and the given test meal were minimized.

The volume of original meal in the stomach was obtained from:

Volume gastric contents $\times$ concentration of marker in gastric contents/Concentration of marker in original meal.

The difference between the volume of the gastric contents recovered (A) and the volume of original meal recovered (B) represents the volume of secre-

Received for publication 27 June 1974. tions in the stomach, plus any residuum of the water used for washing out the stomach before the meal was given. It may be seen that the volume of secretions remaining in the stomach reaches $56 \%$ of the total volume at 90 minutes. Using the method of George it is impossible to separate the contributions of gastric secretion and gastric emptying to changes in the volume of the gastric contents with time. This can be important when comparing groups with different rates of secretion.

This restriction on the interpretation on the results obtained by the method of George can be overcome as follows:

Using the values for 45 minutes in the table, the amount of $\mathrm{Cl}^{-}$in the stomach is given by:

$$
0.271(1) \times 43.3(\mathrm{mM} / 1)=11.7 \mathrm{mM}
$$

Assuming that the mean concentration of $\mathrm{Cl}^{-}$in the secretions entering the stomach is $140 \mathrm{mM} / 1$, (Hunt and Wan, 1968), $\frac{11 \cdot 7}{140}$ gives 0.084 litres, which nearly matches the value of A-B above, 0.089 litres. As can be seen from the other values in the same line in the table, this is a moderately reliable method of computing the volume of secretions in the total gastric contents. To obtain a plot of volume of meal remaining against time, the computed volumes of secretions can be subtracted from the volumes of gastric contents. Chloride can be readily titrated, even in test meals containing buffer.

A merit of the George method is that it provides information about the volume of gastric contents over two hours or more. Information about the second hour may be considerably more valuable if the proportion of the secretion in the gastric contents is known.

\begin{tabular}{|c|c|c|c|c|c|c|}
\hline $\begin{array}{l}\text { Time of sample (min) } \\
\text { A volume gastric contents (1) } \\
\text { B volume meal remaining (1) } \\
\text { Intragastric volume of secretions A-B (1) }\end{array}$ & $\begin{array}{l}15 \\
0.520 \\
0.459 \\
0.061\end{array}$ & $\begin{array}{l}30 \\
0.368 \\
0.282 \\
0.066\end{array}$ & $\begin{array}{l}45 \\
0 \cdot 271 \\
0 \cdot 182 \\
0.089\end{array}$ & $\begin{array}{l}60 \\
0 \cdot 172 \\
0 \cdot 105 \\
0.067\end{array}$ & $\begin{array}{l}75 \\
0.121 \\
0.067 \\
0.054\end{array}$ & $\begin{array}{l}90 \\
0.087 \\
0.038 \\
0.049\end{array}$ \\
\hline$\frac{\mathrm{A}-\mathrm{B}}{\mathrm{A}} 100$ & 12 & 18 & 33 & 39 & 45 & 56 \\
\hline $\begin{array}{l}\text { Concentration in gastric content }\left(\mathrm{mM} / 1 \mathrm{Cl}^{-}\right) \\
\mathrm{C} \text { amount in gastric contents }(\mathrm{mM} \mathrm{Cl}-)\end{array}$ & $\begin{array}{r}14 \cdot 5 \\
7 \cdot 5\end{array}$ & $\begin{array}{l}29 \cdot 9 \\
11 \cdot 0\end{array}$ & $\begin{array}{l}43 \cdot 3 \\
11 \cdot 7\end{array}$ & $\begin{array}{l}59 \cdot 1 \\
10 \cdot 2\end{array}$ & $\begin{array}{r}62 \cdot 0 \\
7 \cdot 5\end{array}$ & $\begin{array}{r}72 \cdot 9 \\
6 \cdot 3\end{array}$ \\
\hline$\frac{C}{140}$ & 0.054 & 0.078 & 0.084 & 0.073 & 0.054 & 0.045 \\
\hline
\end{tabular}

Table Means for measurements in 21 subjects 
Anyone using the method of George would be wise to consult papers by Bandes, Hollander, and Glickstein (1940) and Hollander and Glickstein (1940) which discuss the conditions optimal for the use of dilution indicators.

\section{References}

Bandes, J., Hollander, F., and Glickstein, J. (1940). The effect of fluid absorption on the dilution indicator technique of gastric analysis. Amer. J. Physiol., 131, 470-482.

George, J. D. (1968). New clinical method for measuring the rate of gastric emptying the double sampling test meal. Gut, 9, 237-242.

Hollander, F., and Glickstein, J. (1940). Secretory studies in whole stomachs: the dilution indicator technique and its precision measures. Amer. J. dig. Dis., 7, 386-391.

Hunt, J. N., and Spurrell, W. R. (1951). The pattern of emptying of the human stomach. J. Physiol. (Lond.), 113, 157-168.

Hunt, J. N., and Wan, B. (1967). Electrolytes of mammalian gastric juice. In Handbook of Physiology, Sect, 6, Alimentary Canal. edited by C. F. Code, Vol. II, Secretion, pp, 781-804. American Physiological Society, Washington, D.C.

\section{The September 1974 Issue}

\section{THE SEPTEMBER 1974 ISSUE CONTAINS THE FOLLOWING PAPERS}

Isolation of two minigastrins from ZollingerEllison tumour tissue R. A. GREGORY AND HILDA J. TRACY

Pure human minigastrin: secretory potency and disappearance rate HAILE T. DEBAS, JOHN H. WALSH, AND MORTON I. GROSSMAN

Radioimmunoassay of cholecystokinin-pancreozymin R. F. HARVEY, LYNDA DOWSETT, M. HARTOG, AND A. E. READ

Interaction of pentagastrin and the octapeptide of cholecystokinin on the human lower oesophageal sphincter RICHARD A. L. STURDEVANT AND THOMAS KUN

Effect of calcitonin on the formation, composition, and enzymatic activity of the hepatic bile in guinea pigs A. TARNAWSKI, J. BOGDAT, K. DURA, $z$. MARSZATEK, AND A. JEDRYCHOWSKI

Supersensitivity to pentagastrin in diffuse oesophageal spasm V. ECKARDT AND H. WEIGAND

Lysolecithin: A factor in the pathogenesis of gastric ulceration? A. G. JOHNSON AND SUSAN J. MCDERMOTT
Gastric acid secretions and risk of recurrence of duodenal ulcer within six to eight years after truncal vagotomy and drainage O. KRONBORG

Cellular localization of a vasoactive intestinal peptide in the mammalian and avian gastrointestinal tract JULIA M. POLAK, A. G. E. PEARSE, J-C. GARAUD, AND S. R. BLOOM

An evaluation of the rosette inhibition test in Crohn's disease J. R. CLARKE, E. R. RICHEN $S$ M. J. WILliAMS, K. R. GOUGH, AND R. J. ANCILLA

Luminal distension as a possible consequence of experimental intestinal perfusion DAVID WINGATE, ASHLEY HYAMS, AND SIDNEY PHILLIPS

The epidemiological importance of 'ay' and 'ad' subtypes of the HB-Ag F. PONS-ROMERO, J. HEATHCOTE, AND S. SHERLOCK

A morphometric study of the endoplasmic reticulum in human hepatocytes A. M. JÉZÉQUEL, M. KOCH, AND F. ORLANDI

Progress report Highly selective vagotomy DAVID JOHNSTON

Progress report Laxative abuse JOHN H. CUMMINGS

Copies are still available and may be obtained from the PUBLISHING MANAGER, BRITISTH MEDICAL ASSOOCIATION, TAVISTOCK SQUARE, LONDON, WC̣1H 9JR, price 87 $\frac{1}{2} \mathrm{p}$ 